\title{
Degradation Behavior of High Chromium Sodium-Modified A356.0-Type Al-Si-Mg Alloy in Simulated Seawater Environment
}

\author{
M. Abdulwahab*1, ${ }^{1,}$ I.A. Madugu', S.A. Yaro ${ }^{1}$, A.P.I. Popoola ${ }^{2}$ \\ ${ }^{1}$ Department of Metallurgical and Materials Engineering, Ahmadu Bello University, Zaria, \\ Nigeria \\ ${ }^{2}$ Department of Chemical and Metallurgical Engineering, Tshwane University of Technology, \\ Pretoria, Republic of South Africa \\ *Corresponding Author: mabdulwahab@abu.edu.ng
}

\begin{abstract}
The effect of multiple-step thermal ageing treatment (MSTAT) on the corrosion characteristics of A356.0-type Al-Si-Mg alloy in simulated seawater has been studied. The MSTAT treatment also consists of Double Thermal Ageing (DTAT- T7), Single Thermal Ageing (STAT- T6), StepQuenching and Ageing (SQA). The corrosion of the thermal treated samples was characterized by electrochemical Potentiodynamics polarization techniques consisting of linear polarization and chronopotentiometric method using the fit Tafel plot. Generally, from the linear polarization, the corrosion rate decreases at all temperatures with the ageing time. The corrosion behavior of the DTAT and SQA Al-Si-Mg alloy in the simulated seawater showed better resistance than the STAT Al-Si-Mg alloy. Samples in the SQA-STAT have improved corrosion resistance than the SQA-DTAT one. The chronopotentiometric corrosion study of some selected samples indicates a decrease in the corrosion resistance with open circuit potential exposure time. Consequently, the form of corrosion in the studied Al-Si-Mg alloy are slightly uniform and predominantly pitting corrosion as obtained from the SEM study. The pits diameter were found to range from $30-50 \mu \mathrm{m}$.
\end{abstract}

Key words: pits diameter, MSTAT, degradation behavior, corrosion rate.

\section{INTRODUCTION}

Foundry aluminium alloys based on the Al-Si system are widely used in the automobile field since they provide excellent fluidity and castability, good resistance to corrosion and mechanical 
properties [1-4]. Al-Si alloys are characterized by a wide temperature range in the semi-solid region [1,5]. Al-Si alloys, which comprise $85 \%$ to $90 \%$ of the total aluminium cast parts produced, exhibit excellent castability, mechanical and physical properties [6,7]. Aluminium alloys has successfully penetrated the automotive market, largely ( $>75 \%)$ in the form of castings [8]. Addition of Mg to Al-Si (A356 alloys) is the main solid solution strengthener to aluminium alloys and responsible to precipitation hardening $(\mathrm{PH})$ to yield higher strength [9-12]. A356 alloys contains silicon but also magnesium as main alloying elements. It shows response to heat treatment [1,3,13-16] and increase strength by precipitation of $\mathrm{Mg}_{2} \mathrm{Si}$ in aluminium matrix [1,1724].

Aluminium and its alloys are considered to be highly corrosion resistant under the majority of available service condition [25]. The various grades of pure aluminium are most resistance, followed closely by the Al-Mg, Al-Mn alloys. Next in order is Al-Mg-Si and then Al-Si alloy. The alloy containing copper are the least resistant to corrosion; but this can be improved by coating each side of the copper containing alloy with a thin layer of high purity aluminium, thus gaining a three ply metal, i.e. Alclad. This cladding acts as a mechanical shield and also protects the material by sacrificial [26]. When aluminium surface are exposed to the atmosphere, a thin invisible oxide $\left(\mathrm{Al}_{2} \mathrm{O}_{3}\right)$ skin forms, which protects the metal from corrosion in many environments [25]. This film protect the metal from further oxidation unless this coating is destroyed, the material remains fully protected against corrosion $[27,28]$. The composition of an alloy and its thermal treatment are of important for susceptibility of alloys to corrosion [29].

In the development and processing of aluminium alloys, various works have been reported on the degradation of the alloys at various environment and operating conditions. Several methods of controlling and preventing or minimizing corrosion attach in aluminium alloys have been demonstrated by different authors. Alloying addition have been reported to successfully reduced corrosion attack in aluminium alloy [30,31]. Other methods of corrosion control include inhibitors addition [32-34]. Heat treatment (PH) (including DTAT) [31,35-40]. Corrosion resistance of $\mathrm{Al}-\mathrm{Si}-\mathrm{Mg}$ alloy is much better than the aluminium-copper alloys [41]. On the microstructural and submicroscopic scales, the electrochemical properties develop point-to-point non-uniformities that account for changes in resistance of the alloy [42]. Abdulrahman and Agbodion [43] studied the effect of ageing time and temper on the corrosion of Al-Si-Cu alloy in varying $\mathrm{HCl}$ concentrated acid solution. They noticed that the rate of corrosion of the alloy increased with increase in concentrations of the acid and decreased sharply with time.

Khoshnaw and Gardi [44] studied the effect of ageing time and temperature on exfoliation corrosion of aluminium alloys 2024-T3 and 7075-T6. They observed that with increase in the ageing time for aluminium alloy type 2024-T3, the susceptibility to exfoliation corrosion increase while for the 7075-T6 decreased. The intermetallic compounds formed such as $\mathrm{CuAl}_{2}$ and $\mathrm{MZn}_{2}$ phase increase with increase in ageing time for both alloys. Aluminium alloys has 
been used for along time because of it essential properties. New demanding applications are developed continuously. To be able to make the alloys competitive in future applications, assess to powerful tools and methods for materials or/ properties development is essential. The interest in this work for DTAT and SQA treatments comes from the possibility to improve the corrosion resistance of Al-Si-Mg alloy in the T6 temper. It is on this note that an electrochemical corrosion test consisting of linear polarization and chronopotentiometric as a means of corrosion assessment of this group of alloy was carried out after these novel thermal treatments.

\section{MATERIALS AND METHODS}

The A356.0-type Al-Si-Mg alloy with chemical composition (see Table 1) was produced according to the methods described elsewhere [30,45]. Some seconds to pouring of the molten alloy into the mould, $0.01 \%$ elemental sodium was added and stirred thoroughly. The cast samples were machined to specified electrochemical corrosion dimensions at the Centre for Advanced Manufacturing Technology (CAMT), Tshwane University of Technology, Soshanguve, Pretoria, Republic of South Africa.

Table 1. Chemical composition of the produced A356.0-type Al-Si-Mg alloy (wt \%).

\begin{tabular}{|l|l|l|l|l|l|l|l|l|l|l|l|}
\hline $\mathrm{Al}$ & $\mathrm{Si}$ & $\mathrm{Mg}$ & $\mathrm{Fe}$ & $\mathrm{Mn}$ & $\mathrm{Cr}$ & $\mathrm{Pb}+\mathrm{Sn}$ & $\mathrm{Zn}$ & $\mathrm{Cu}$ & $\mathrm{Ti}$ & $\mathrm{Ni}$ & $\mathrm{Na}$ \\
\hline 92.14 & 7.00 & 0.30 & 0.08 & 0.03 & 0.20 & 0.03 & 0.05 & 0.03 & 0.11 & 0.03 & 0.01 \\
\hline
\end{tabular}

The electrochemical potentiodynamics technique was used to characterize the corrosion rate (current densities) consisting of linear polarization and chronopotentiometric or open circuit potential (OCP). A potentiostat coupled to a computer system, a glass corrosion cell kit with a platinum counter electrode and a saturated $\mathrm{Ag} / \mathrm{Ag}$ reference electrode were used. The working electrodes consist of thermally aged alloys. The samples were positioned at the glass corrosion cell kit, leaving a $3.803 \mathrm{~cm}^{2}$ alloy surfaces in contact with the solution. Polarization test were carried out in a $3.5 \mathrm{wt} \% \mathrm{NaCl}$ solution at room temperature (RT) using a potentiostat. The polarization curves were determined by stepping the potential at a scan rate of $0.003 \mathrm{~V} / \mathrm{sec}$. The polarization curves were plotted using Autolab data acquisition system (Autolab model: AuT71791 and PGSTAT 30), and both the corrosion rate and potential were estimated by the Tafel extrapolation method (Tafel plot or corrosion rate analysis) using both the anodic and cathodic branches of the polarization curves. The chronopotentiometric (OCP) was also used to assess the corrosion behavior of some alloys samples in order to determine whether there was prolong or short passive or active condition. The electrochemical corrosion test was done at Department of Chemical and Metallurgical Engineering, Tshwane University of Technology, Pretoria, Republic of South Africa. 


\section{RESULTS AND DISCUSSIONS}

\subsection{Results}

The corrosion rate analysis from the linear polarizations using the data from the Tafel plots have been represented in the normal form; shown as Figures 1-6 and the OCP curves are presented as Figure 7. The SEM of the surface morphology of some treated as-corroded samples can be found in Plates 1-5.

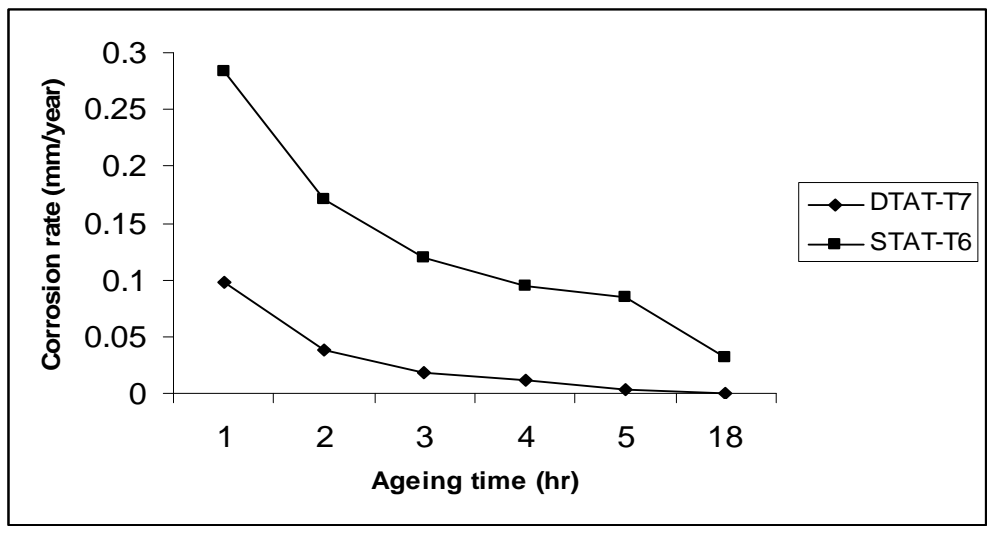

Figure 1: Variation of corrosion rate with ageing time for DTAT-T7 and STAT-T6 A356.0-type Al-Si-Mg alloy at $150^{\circ} \mathrm{C}$ from the Tafel plot data in simulated seawater environment.

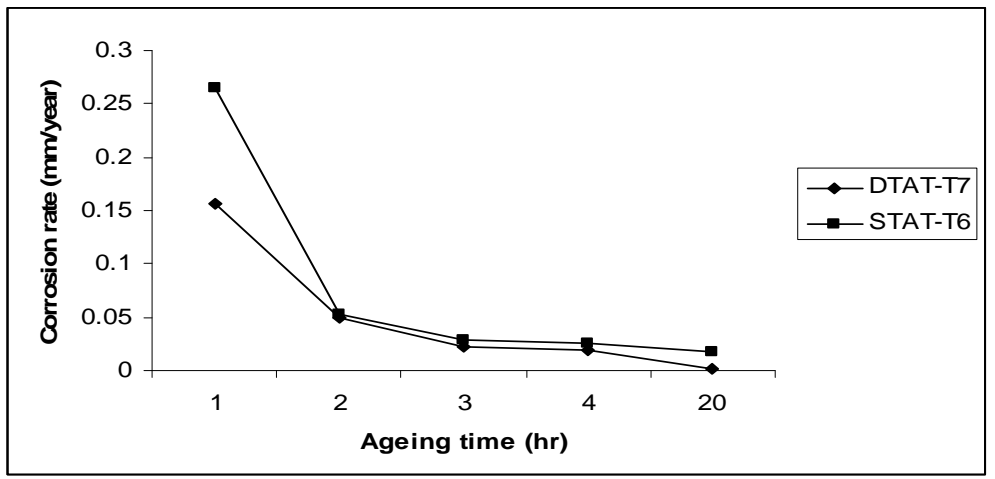

Figure 2: Variation of corrosion rate with ageing time for DTAT-T7 and

STAT-T6 A356.0-type Al-Si-Mg alloy at $180^{\circ} \mathrm{C}$ from the Tafel plot data in simulated seawater environment. 


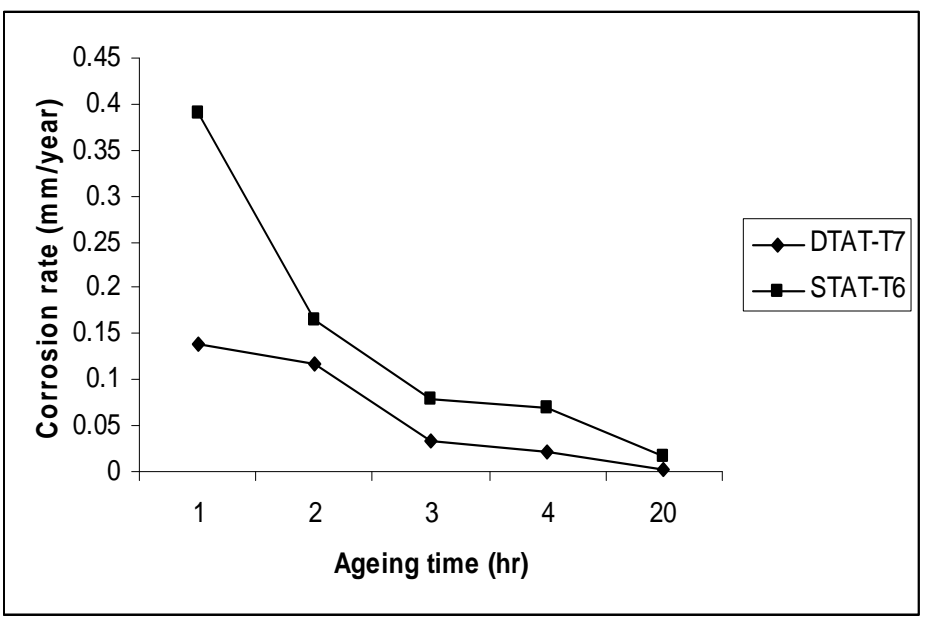

Figure 3: Variation of corrosion rate with ageing time for DTAT-T7 and STAT-T6 A356.0-type Al-Si-Mg alloy at $210^{\circ} \mathrm{C}$ from the Tafel plot data in simulated seawater environment.

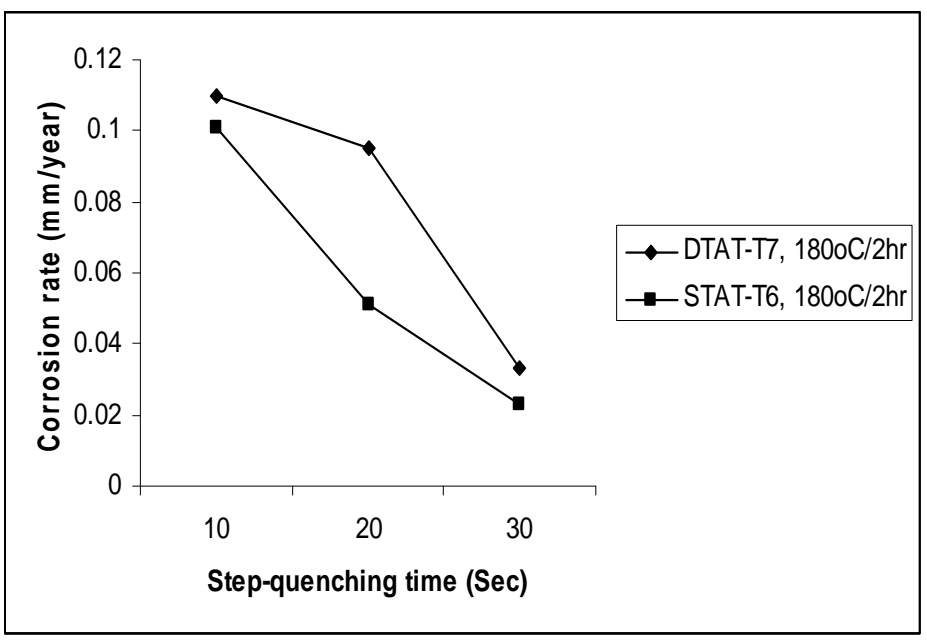

Figure 4: Variation of corrosion rate with ageing time for DTAT-T7 and STAT-T6 A356.0-type Al-Si-Mg alloy at $220^{\circ} \mathrm{C}$ SQ temperature and aged $180^{\circ} \mathrm{C} / 2 \mathrm{hr}$ from the Tafel plot in simulated seawater environment. 


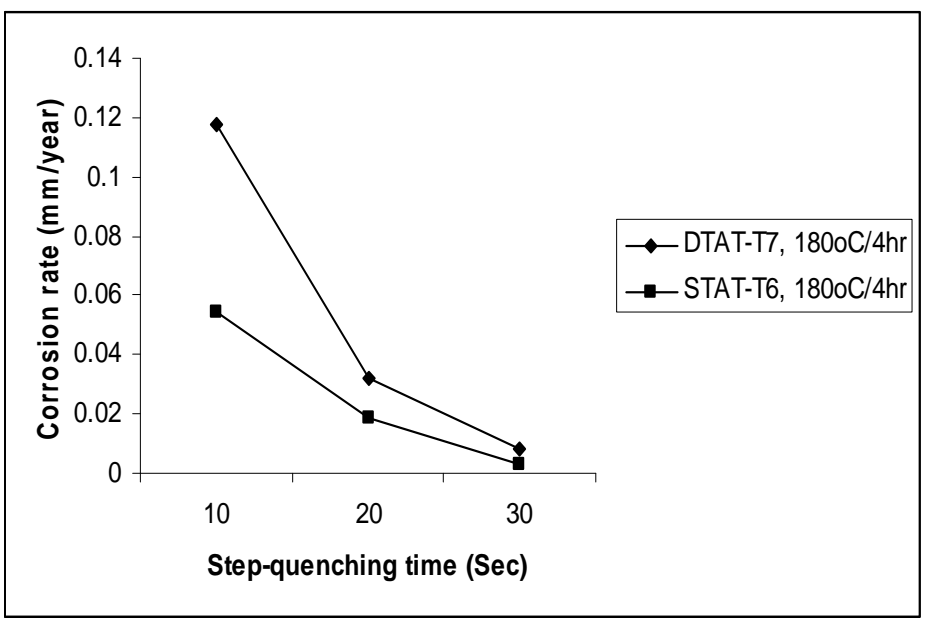

Figure 5: Variation of corrosion rate with ageing time for DTAT-T7 and STAT-T6 A356.0-type Al-Si-Mg alloy at $220^{\circ} \mathrm{C}$ SQ temperature and aged at $180^{\circ} \mathrm{C} / 4 \mathrm{hr}$ from the Tafel plot in simulated seawater environment.

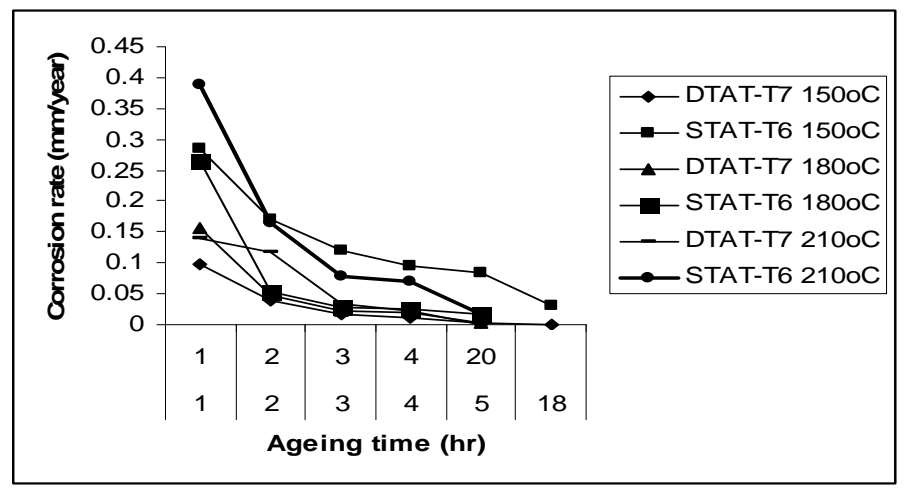

Figure 6: Comparative study of corrosion rate for DTAT-T7 and STATT6 A356.0-type Al-Si-Mg alloy at $150^{\circ} \mathrm{C}, 180^{\circ} \mathrm{C}$ and $210^{\circ} \mathrm{C}$ at various ageing time from the Tafel plot data in simulated Seawater environment 


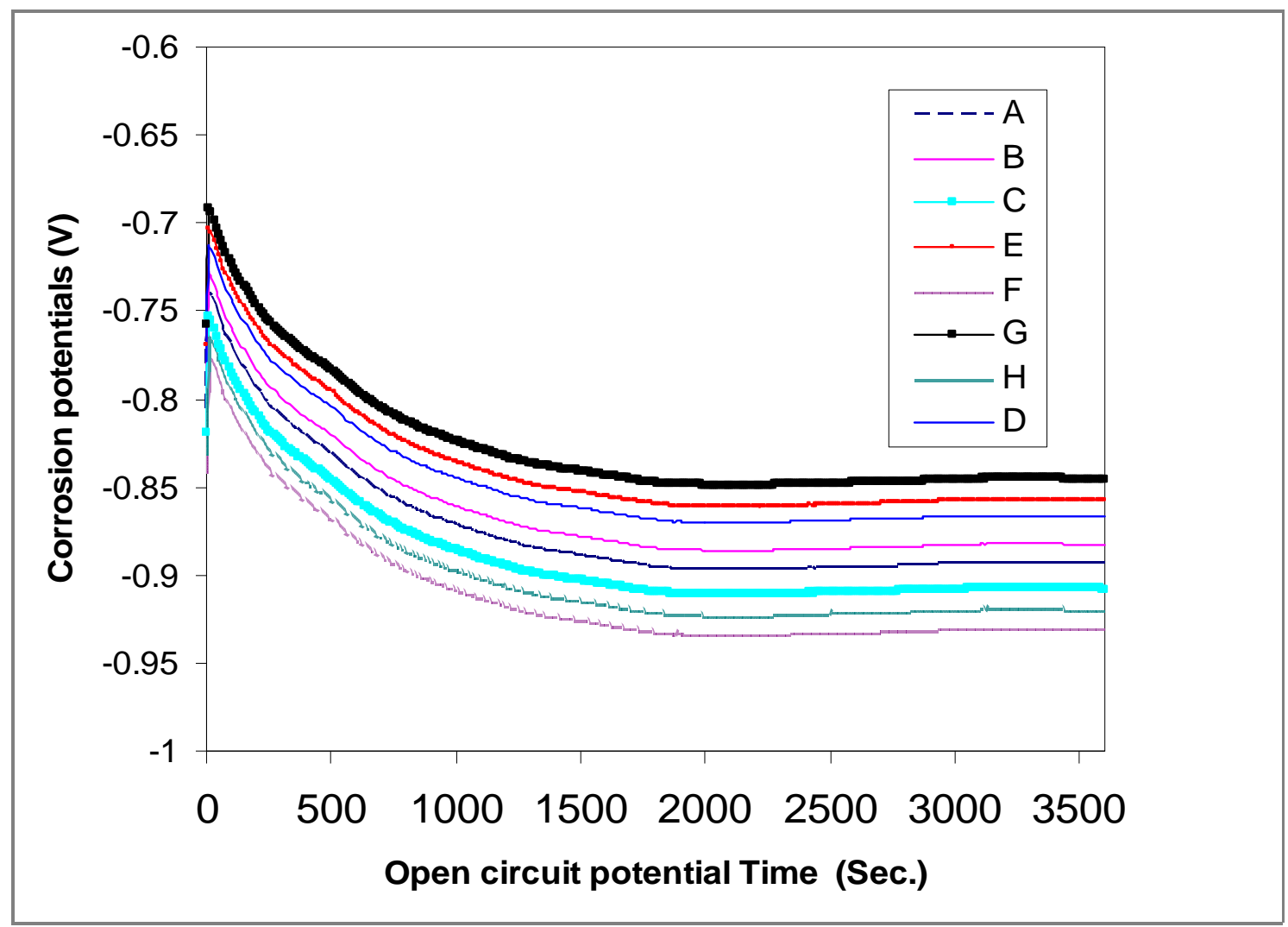

Figure 7: Chronopotentiometric curve for some selected DTAT and STAT A356.0-type alloys (A) STAT-T6 $150^{\circ} \mathrm{C} / 18 \mathrm{hr}$ (B) STAT-T6, $180^{\circ} \mathrm{C} / 20 \mathrm{hr}$ (C)STAT-T6, $210^{\circ} \mathrm{C} / 20 \mathrm{hr}$ (D)DTAT-T7, $180^{\circ} \mathrm{C} / 20 \mathrm{hr}$ (E)DTAT-T7 $210^{\circ} \mathrm{C} / 20 \mathrm{hr}$ (F)SQA DTAT-T7, $220^{\circ} \mathrm{C} / 3$ Osec., $180^{\circ} \mathrm{C} / 4 \mathrm{hr}$ (G)DTATT7 $150^{\circ} \mathrm{C} / 18 \mathrm{hr}(\mathrm{H}) \mathrm{SQA}$ STAT-T6, $220^{\circ} \mathrm{C} / 3 \mathrm{Osec} ., 180^{\circ} \mathrm{C} / 4 \mathrm{hr}$

\subsection{Discussion of Results}

\subsubsection{Corrosion characteristics}

\subsubsection{Potentiodynamics linear polarization and MSTAT treatment}

From Figures 1-6, the potentiodynamics polarization curves for A356.0-type Al-Si-Mg alloy subjected to different MSTAT treatment in a $3.5 \mathrm{wt} \% \mathrm{NaCl}$ are presented. However, the corrosion rate decreases with increasing ageing time (see Figures 1-6) for all the DTAT, STAT, SQA; DTAT and STAT samples considered. This is in agreement to those reported $[43,44,46-$ 49]. The corrosion rate of DTAT and STAT samples at $150^{\circ} \mathrm{C}, 180^{\circ} \mathrm{C}$ and $210^{\circ} \mathrm{C}$ decreases with increasing ageing time (1-20hr). The DTAT treatment has demonstrated a remarkable decrease in the corrosion rate than STAT samples at all ageing time. For example, at $150^{\circ} \mathrm{C} / 1 \mathrm{hr}$ DTAT and STAT, the corrosion rates are 0.09766 and $0.284 \mathrm{~mm} /$ year respectively. While at $18 \mathrm{hr}$ same 
temperature, DTAT and STAT corrosion rates are 0.0002171 and $0.03093 \mathrm{~mm} /$ year respectively. However, similar results [50] and trends [48] have been reported. On the other hand, since the grain boundaries are often more susceptible to corrosion than the grain interiors because of the microstructural heterogeneity associated with grain boundaries [38,51,52]. It is expected that samples with higher have pronounced grain boundaries, as such higher hardness is expected for such sample. For all the DTAT samples investigated, the corrosion rate has been observed to be significantly lower than that obtained at the STAT condition for all ageing temperatures and time comparatively. One of the reasons for this behavior is that the pre-ageing treatment at $105^{\circ} \mathrm{C} / 5 \mathrm{hr}$ in the DTAT is responsible for these decreases in the corrosion rate compare to those observed with the STAT samples. The phases formed which enhanced hardness may probably have some deleterious effect on the physicochemical properties of the alloy in the electrochemical polarization condition.

However, the SQA; DTAT-T7 at $180^{\circ} \mathrm{C} / 2 \mathrm{hr}$ and $4 \mathrm{hr}$ have higher corrosion rate than those of SQA; STAT-T6 at $180^{\circ} \mathrm{C} / 2 \mathrm{hr}$ and $4 \mathrm{hr}$ for all the step-quenching time considered (see figure 4 and 5). For example the current densities at SQA; DTAT-T7 at $180^{\circ} \mathrm{C} / 2 \mathrm{hr}$ and $4 \mathrm{hr}$ $\left(220^{\circ} \mathrm{C} / 30\right.$ sec.) are 2.031 and $0.5 \mu \mathrm{A} / \mathrm{cm}^{2}$ as compared to those at SQA; STAT at $180^{\circ} \mathrm{C} / 2 \mathrm{hr}$ and $4 \mathrm{hr}\left(220^{\circ} \mathrm{C} / 30 \mathrm{sec}\right)$, the current densities are 1.419 and $0.1696 \mu \mathrm{A} / \mathrm{cm}^{2}$ respectively. This results showed a very wide difference in the corrosion rate of the two conditions indicating that SQA; DTAT-T7 are more susceptible to corrosion attach than SQA; STAT-T6 samples within the studied conditions.

It is also believed that after quenching, particles of the second phase precipitates occurred which affect the physicochemical properties of the alloy. The ageing temperatures and the degree of supersaturation play a major role in the final properties of the alloy. However, as the ageing progresses, the inter-atomic spacing and the bond between the molecules changed which account for the electrochemical behavior of these samples. Such tendency agreed with the results obtained in previous study [29, 46]. The corrosion resistances of A356.0-type Al-Si-Mg alloy studied seems to be strongly associated not only with the distribution of eutectics which is dependent on the interdendritic spacing, but also with the fineness of the eutectic inter-phase spacing.

Comparatively, samples aged at $150^{\circ} \mathrm{C}$ for $18 \mathrm{hr}$ at DTAT exhibit the highest corrosion resistance in $3.5 \mathrm{wt} \% \mathrm{NaCl}$ solution simulated environment considered in this work. The sequence below presents the decreasing order of corrosion resistance of the sample at various ageing temperature and time: 
DTAT-T7, $150^{\circ} \mathrm{C} / 18 \mathrm{hr}$

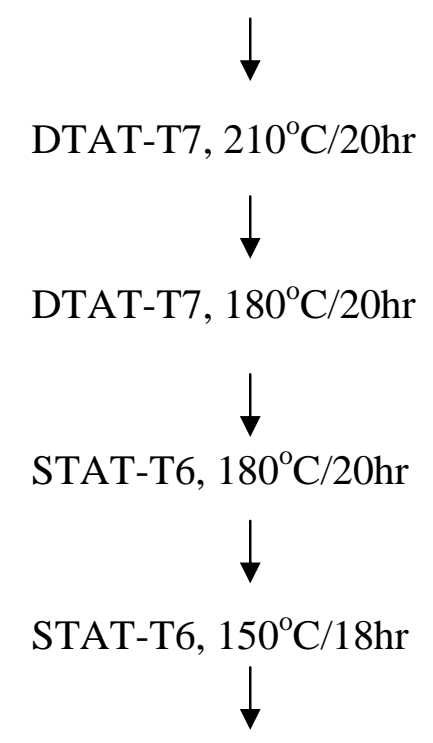

STAT-T6, $210^{\circ} \mathrm{C} / 20 \mathrm{hr}$

and

$$
\begin{aligned}
\text { SQA } 180^{\circ} \mathrm{C} / 4 \mathrm{hr} \text {; STAT-T6 } & \rightarrow \text { SQA } 180^{\circ} \mathrm{C} / 4 \mathrm{hr} \text {; DTAT-T7 } \\
\text { SQA } 180^{\circ} \mathrm{C} / 2 \mathrm{hr} \text {; STAT-T6 } & \rightarrow \text { SQA } 180^{\circ} \mathrm{C} / 2 \mathrm{hr} \text {; DTAT-T7 }
\end{aligned}
$$

The results above motivated the interest in examining the samples of best corrosion resistance at each ageing temperature considered using the chronopotentiometric analysis which enables the evaluation of the corrosion kinetic of the selected sample through corrosion potentials with prolong time.

\subsubsection{Chronopotentiometric and MSTAT treatments}

From the OCP study of the selected samples of higher corrosion resistance, the corrosion potential, E (V), decreases with the electrochemical exposure time (see Figure 7). This becomes stable (passive) throughout the study time. This shows that the resistances of the thermally treated alloy to corrosion attach decreases with increasing electrochemical exposure time and that the samples later developed passivity (protection against corrosion). At this 'stable-level', it is assumed that the sample has some level of passivity and immunity as a result of the corroding products which covers the corroding surface and retard/stabilizes corrosion attach. These observations have been reported $[47,50]$. It can also be observed, for example, that sample with highest corrosion resistance still have the best corrosion potential $\left(\mathrm{T} 7150^{\circ} \mathrm{C} / 18 \mathrm{hr}\right)$ indicating higher corrosion resistance in $3.5 \mathrm{wt} \% \mathrm{NaCl}$ solution. 


\subsubsection{Microstructures and degradation behavior after corrosion study of A356.0-type Al-Si-Mg alloy}

The microstructure of some selected as-corroded samples after electrochemical corrosion study using SEM indicates some traces of cracks and pronounced pits; showing that the samples have suffered pitting corrosion attach (Plates 1-5). The exposure surface shows evidence of localized attach at the location of the intermetallic caused by the dissolution of the matrix. There was evidence of corroding products of intermetallic compounds in all the samples examined. Besides, several pits are visible in all samples examined at different magnifications; x300, x1000, x10000. In Plates 1 and 3 there seems to be uniform surface pits formations which are less deep as compared to those in Plates 2, 4 and 5. More pronounced deeper pit were seen in $\mathrm{T} 6150^{\circ} \mathrm{C} / 3 \mathrm{hr}$ (Plate 4) and SQA T7 $220^{\circ} \mathrm{C} / 20 \mathrm{sec} \cdot 180^{\circ} \mathrm{C} / 2 \mathrm{hr}$ (see Plate 5).

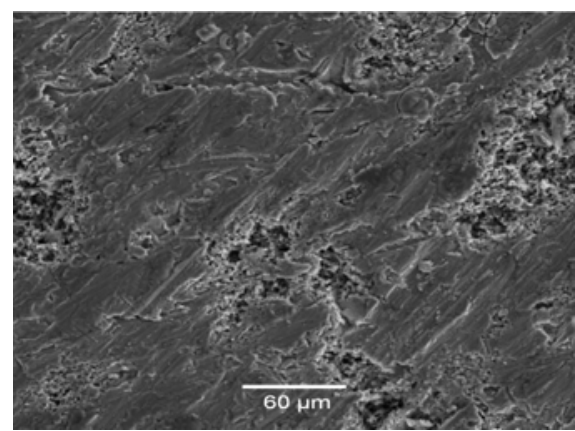

T7 $180^{\circ} \mathrm{C} / 20 \mathrm{hr}$ x300

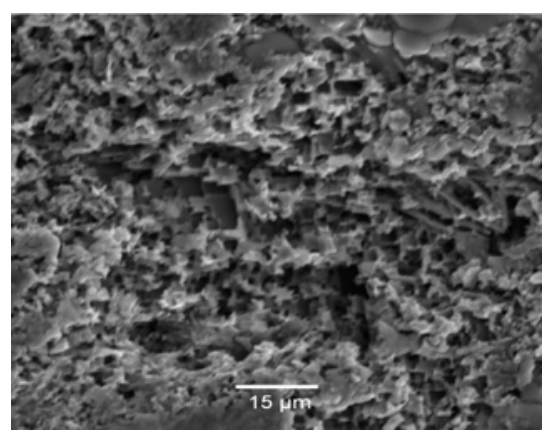

$\mathrm{T} 7180^{\circ} \mathrm{C} / 20 \mathrm{hr} \mathrm{x} 1000$

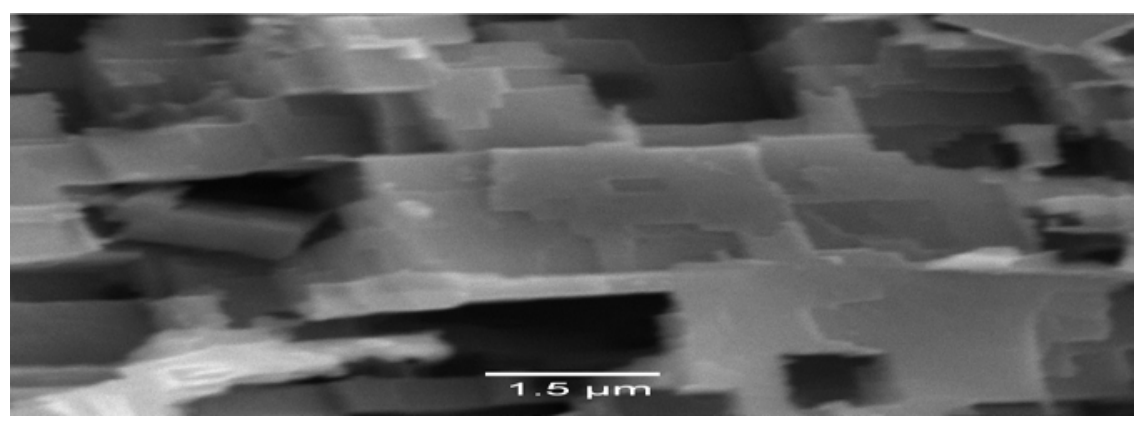

$\mathrm{T} 7180^{\circ} \mathrm{C} / 20 \mathrm{hr} \times 10,000$

Plate 1: SEM Secondary Electron Image of the damaged surface Morphology of as- corroded T7 $180 / 20 \mathrm{hr}$ in $3.5 \mathrm{wt} \% \mathrm{NaCl}$ Solution. Microstructures at different magnifications indicates several and severe pits. 


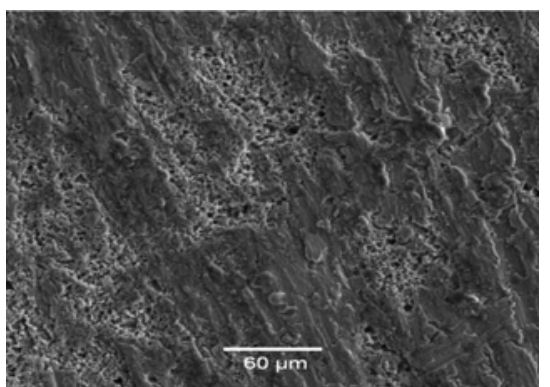

T6 $180^{\circ} \mathrm{C} / 2 \mathrm{hr} \times 300$

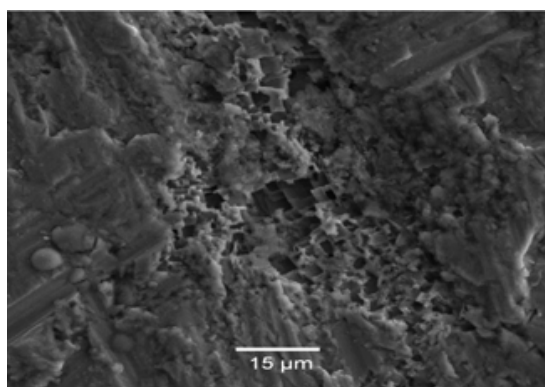

T6 $180^{\circ} \mathrm{C} / 2 \mathrm{hr} \mathrm{x} 1000$

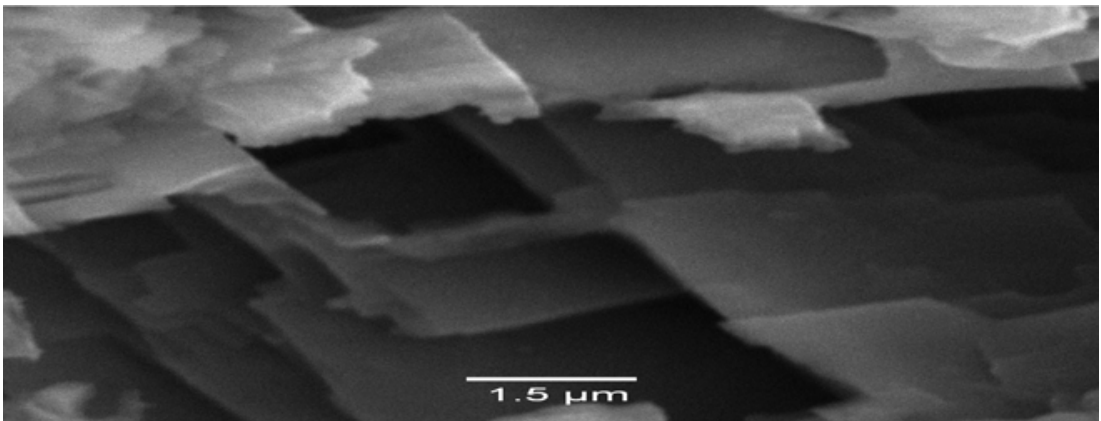

T6 $180^{\circ} \mathrm{C} / 2 \mathrm{hr} \times 10,000$

Plate 2: SEM Secondary Electron Image of the damaged surface Morphology of as-corroded T6 $180 / 2 \mathrm{hr}$ in $3.5 \mathrm{wt} \% \mathrm{NaCl}$ Solution. Microstructures at different magnifications indicate several and severe pits higher than those observed in plate 10a.

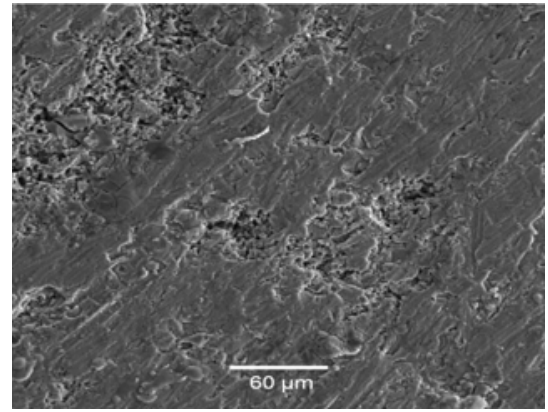

$\mathrm{T} 7150^{\circ} \mathrm{C} / 4 \mathrm{hr} \times 300$

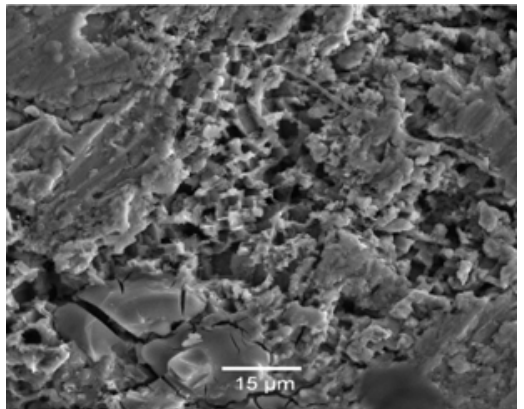

T7 $150^{\circ} \mathrm{C} / 4 \mathrm{hr} \times 1000$

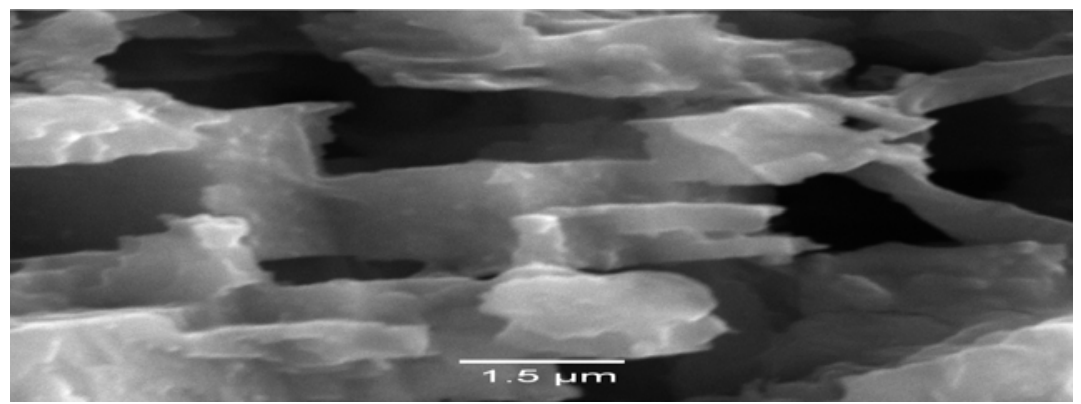

$\mathrm{T} 7150^{\circ} \mathrm{C} / 4 \mathrm{hr} \mathrm{x} 10,000$

Plate 3: SEM Secondary Electron Image of the damaged surface Morphology of as-corroded T7 $150 / 4 \mathrm{hr}$ in $3.5 \mathrm{wt} \% \mathrm{NaCl}$ Solution. Microstructures at different magnifications indicates several and severe pits. Indicating traces of cracks. 


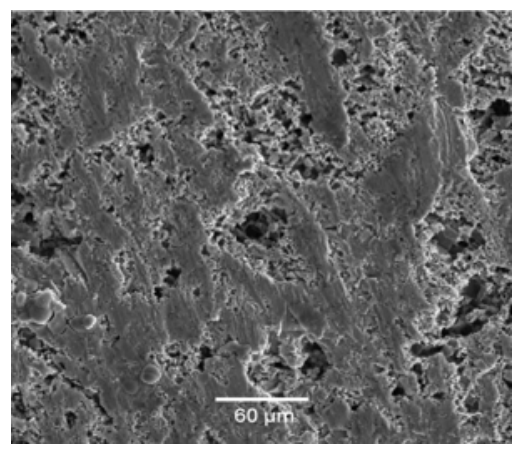

T6 $150^{\circ} \mathrm{C} / 3 \mathrm{hr} \mathrm{x} 300$

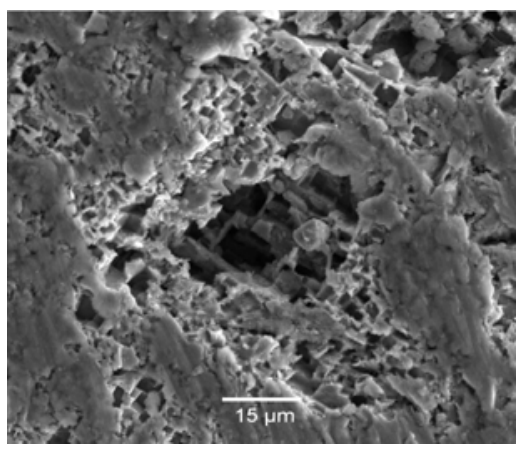

T6 $150^{\circ} \mathrm{C} / 3 \mathrm{hr} \mathrm{x} 1000$

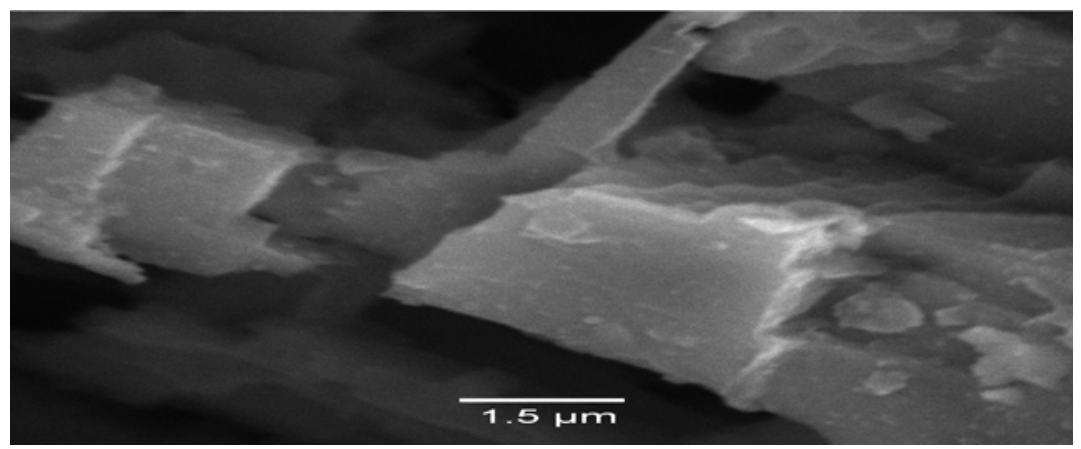

T6 $150^{\circ} \mathrm{C} / 3 \mathrm{hr} \mathrm{x} 10,000$

Plate 4: SEM Secondary Electron Image of the damage surface Morphology of as-corroded T6 $150 / 3 \mathrm{hr}$ in $3.5 \mathrm{wt} \% \mathrm{NaCl}$ solution. Microstructures at different magnifications indicate severe pits deeper and wider than those observed in plate 10a, b, c.

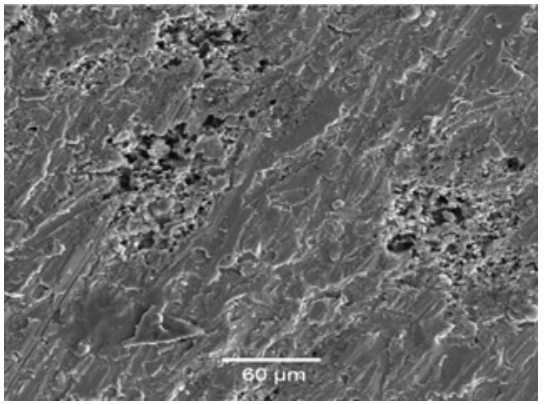

SQA T7 $220^{\circ} \mathrm{C} / 20$ sec. $180^{\circ} \mathrm{C} / 2 \mathrm{hr}$ x300

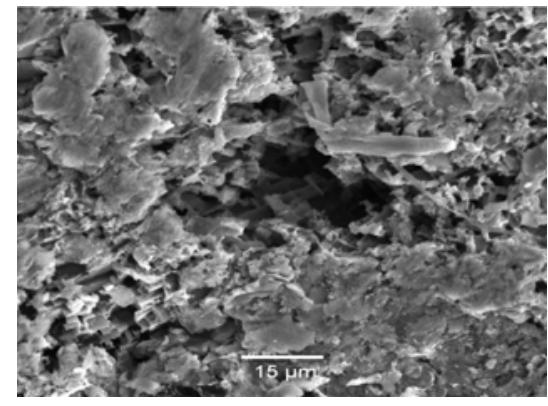

SQA T7 $220^{\circ} \mathrm{C} / 20$ sec. $180^{\circ} \mathrm{C} / 2 \mathrm{hr} \times 1000$

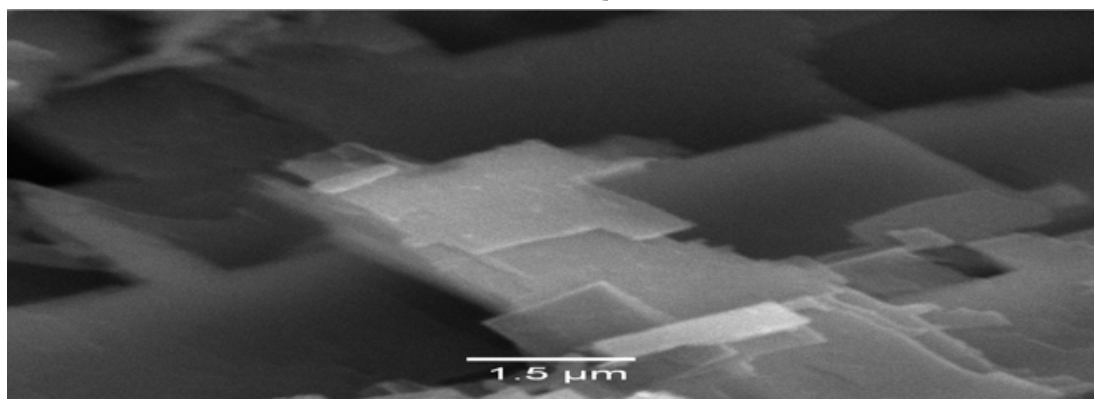

SQA T7 $220^{\circ} \mathrm{C} / 20$ sec. $180^{\circ} \mathrm{C} / 2 \mathrm{hr}$ x 10,000

Plate 5: SEM Secondary Electron Image of the damaged surface Morphology of as-corroded SQA $\mathrm{T} 7220^{\circ} \mathrm{C} / 20 \mathrm{sec} .180^{\circ} \mathrm{C} / 2 \mathrm{hr}$ in $3.5 \mathrm{wt} \% \mathrm{NaCl}$ solution. Microstructures at different magnifications indicate severe pits deeper and wider than those observed in plate 10a, b, c. 
The resultants pits diameter have been determined from the SEM surface morphology to range between $30-50 \mu \mathrm{m}$. Specifically in $\mathrm{T} 6180^{\circ} \mathrm{C} / 2 \mathrm{hr}$ (see Plate 2) the pit diameter are averages of 44.4445 and $50 \mu \mathrm{m}$. It is probable that the pits are formed by intermetallic dropping out from the surface due to the dissolution of the surrounding matrix. However, it is also possible that the pits are caused by selective dissolution of the intermetallic/or particles of the second phase precipitates. Consequently, the form of corrosion in the studied samples A356.0-type Al-Si-Mg alloy are slightly uniform and predominantly pitting corrosion as obtained by the SEM.

\section{CONCLUSIONS}

(1) From the linear polarization and Tafel extrapolation plot, the corrosion rate decreases at all temperatures with the ageing time.

(2) The corrosion of the DTAT and SQA A356.0-type Al-Si-Mg alloy in the simulated Seawater showed better resistance than the STAT A356.0-type Al-Si-Mg alloy.

(3) Those samples in the SQA-STAT have improved corrosion resistance than the SQA DTAT samples. The chronopotentiometric corrosion study of some selected samples indicate a decrease and stability in there corrosion resistance with electrochemical exposure time.

(4) Consequently, the forms of corrosion in the studied A356.0-type Al-Si-Mg alloy are uniform pitting corrosion as obtained from the SEM study with pits diameter ranging from $30-50 \mu \mathrm{m}$.

\section{ACKNOWLEDGEMENTS}

The authors would like to thank the Department of Chemical and Metallurgical Engineering, TUT, South Africa for the equipment support. The technical assistance of Mrs. Adams Feyisayo at Department of Chemistry, University of Johannesburg, Johannesburg, Republic of South Africa during the corrosion test is highly appreciated.

\section{REFERENCES}

[1] Leo, P., Cerri, E., 2003, "Silicon Particle Damage in a thioxocast A356 Alminium Alloy.” Met Sci and Tech, Teksid Aluminiums Journal, Vol. 21, No.1, pp. 27-31.

[2] El Sebaie, O. Samuel, A. M., Samuel, F. H., Doty, H. W., 2008, "The effects of Mischmetal Cooling rate and heat treatment on the eutectic Si particle Characteristics of A319.1, A356.2 and A413.1 Al-Si casting alloys.” Mater Sci and Eng A480, pp.342-355.

[3] Haghshenas, M., Zarei-Hanzaki, A., Fatemi-Varzaneh, S. M., 2008, "The effects of thermomechanical parameters on the microstructure of thixocast A356 Aluminium alloy.” Mater Sci and Eng A 480, pp.68-74. 
[4] Hassan, S. B., Aigbodion, V. S., 2009, “The effect of thermal ageing on microstructure and mechanical properties of Al-Si-Fe/Mg alloys.” J alloys and compds, 486, pp.309-314.

[5] Caceres, C. H., Selling, B. I., 1997, "Casting defects and tensile properties of an Al- SiMg casting alloy.” Mater Sci and Eng A 220, pp.109 - 116.

[6] Ejiofor, J. U., Reddy, R. G., 1997, JOM, 49, 31.

[7] Nwajagu, C. O., 19994, "Foundry Theory and Practice" ABC Publishers Ltd, Enugu, Nigeria

[8] Hadley, S. W., Das, S., Miller, J. W., 2000, “Aluminium Research and Development (R \& D) for automotive uses and the Dept. of Energy's Role.” An R and D report/findings for the Energy Division, office of advanced automotive technologies US (ORNL/TM-1999 /157) pp. 1-7

[9] Feng Wang, Jishan Zhang, Baiqing Xiong, Yongan Zhang, 2009, “Effect of Fe and Mn additions on microstructure and Mechanical Properties of spray-deposited Al 20Si - 3Cu1Mg alloy.” Mater Charecter, 60, pp.384-388.

[10] Hamani, M. S., Hamidane, F., Djouama, M. C., 2007, “Contribution to assessment of structural Hardening of the solid solution of AS7G06 alloy.” Research Journal of Applied Sciences 2 (1), pp.105-110.

[11] Vijendra, Singh 2007, "Heat treatment of metals." Standard publisher Distributors, Delhi,

[12] Lopez Ismeli Alfonso, Giantitemoc Maldonado Zepeda, Jose Gonzalo Gonzalez Reyes, Ariosto Medina Flores, Juan Serrate Rodriguez, Luis Bejar Gomez, 2007, “TEM Mictrosctructural characterization of mett-spun aged Al-6Si-3Cu x Mg alloys.”Mater character, 58, pp.509-518.

[13] Juang, Shueiwan H., Wu Shyh - Ming, 2008, "Study on Mechanical properties of A356 alloys enhanced with preformed thioxotropic structure.” J. Marine Sci and Tech, Vol. 16, No 4, pp. 271-274.

[14] Tash, M., Samuel, F. H., Mucciardi, F., Doty, H. W., 2007, "Effect of metallurgical Parameters on the hardness and microstructural characterization of as-cast and heattreated 356 and 319 Aluminium alloys. Mater Sci and Eng A443, pp.185-201.

[15] Haghshenas, M., Zarei-Hanzaki, A., Fatemi-Varzaneh, S. M., Abeli, H., 200b, “Hot deformation behaviour of thixocast A356 aluminium alloy during compression at elevated temperature, www. P_Ha_400.

[16] Kliauga, A. M., Vieira, E. A., Ferrante, M., 2008, "The influence of impurity level and tin addition on the ageing heat treatment of the 356 class alloy." Mater Sci and Eng A 480, pp. 5-16.

[17] Johan Zandar, Rolf Sandstrom, 2008, "One parameter model for strength properties of hardenable aluminium alloys.” Materials and Design, vol 29, pp.1540-1548.

[18] Thompson, S., Cockcroft, S. L., Wells, M. A., 2004, "Advanced Light metals casting development: Solidification of aluminium alloy A356.” J. Mater Sci. and Tech, Vol. 20, pp.194-200. 
[19] Jose Luis Cavazos, Rafel Colas, 2001, "Precipitation in a heat-treated aluminium alloy cooled at different rates.” Mater Charact, 47, pp.175- 179.

[20] Evren Tan, Bilgehan Ogel, 2007, “ Influence of heat treatment on the mechanical properties of AA6066 alloy.” Turkish J. Eng. Env. Sci., 31, pp. 53-60.

[21] Khomamizah, F., Ghasemi, A., 2004, "Evaluation of Quality Index of A-356 aluminium alloy by microstructural analysis.” Scientia Iranica, Vol. 11, No 4, pp.336 -391.

[22] Daniel Henkel, Alan W. Pense, 2002, "Structure and properties of Engineering Materials." 5th Edition, McGraw-Hill Series, New York, pp. 292-294.

[23] Yucei Birol, 2009, "Response to artificial ageing of dentritic and globular Al-7\%SiMg alloys.” J. Alloy and Compds, 484, pp.164-167.

[24] Hirth, S. M., Marshall, G. J., Court, S. A., Lloyd, D. J., 2001, "Effect of Si on the ageing behavior and formability of aluminium alloys based on AA6016.” Mater Sci and Eng A319-321, pp.453-456.

[25] Fontana, M. G., Greene, N.D., 1987, “Corrosion Engineering McGraw-Hill book Company, New York, pp. 8-29.

[26] Rollason, E. C., 1964, “Metallurgy for Engineers.” Reprinted Edition, Richard Clay and Company Ltd., Bungay, pp.304 - 306.

[27] Avner, S. H., 1974, “Introduction to Physical Metallurgy.” $2^{\text {nd }}$ Edition McGraw-Hill Inc. London, pp. 481-497.

[28] Scamans, G.M., Hunter, J.A., Holroyd, N.J.H., 1989, “Corrosion of aluminium - a new approach.” Proc. of 8th Inter. Light metals Congress, Leoban Wien, pp. 699-705,

[29] Czechowski, M., 2007, "Effect of anodic polarization on stress corrosion cracking of some aluminium alloy.” Adv. Mater Sci, Vol. 7, No1(11), pp.13-20.

[30] Abdulwahab, M., "The effect of $\mathrm{Mn}$ and $\mathrm{Cr}$ on the mechanical properties and corrosion resistance of $\mathrm{Al}-\mathrm{Si}-\mathrm{Fe}-\mathrm{MnCr}$ alloy in $0.5 \mathrm{M} \mathrm{HCl}$ solution.” M.Sc thesis, Department of Metallurgical and Materials Engineering, Ahmadu Bello University, Zaria, Nigeria.

[31] Fang Hua-Chan, Chen Kang-hua, Zhang Zhou, Zhu Changjun, 2008, "Effect of Yb additions on microstructures and properties 7A60 aluminium alloy." Transactions of nonferrous metals society of China, 18, pp.28-32.

[32] Xue, G., Ding, J., 1990, J. Appl. Surf. Sci., 40, pp.327.

[33] Xue, G., Ding, J., Lu, P., Dong, J., 1991, J. Phys. Chem., 95, 7380.

[34] Tornkvist, C., Thiery, D., Bergam, J., Liedberg, B., Leygraf, C., 1989, J. Electrochem. Soc., 136, 58.

[35] Wang Zi-Xing, Zhang Yong-an, Zhu Bao-hong, Liu Hong-Wei, Wang fang, Xong, Baiquing, 2006, "Tensile and high cycle fatique properties of spray formed Al10.8 Zn2.9Mg 1.9Cu alloys after two-stage ageing treatment." Transaction of the nonferrous Metal Society of China, 16, pp.802-812.

[36] Li Jin-Feng, Peng Zhuo-wei, Li Chao- Xing, JiaZthi-qiang, Chen Wen-jing, Zheng Zi-qiao, 2008, "Mechanical properties, corrosion behaviour and microstructures of 7075 aluminium 
alloy with various ageing treatments." Transaction of the Nonferrous Metal Society of China, 18, pp.755- 762.

[37] Wang, D., Ni, D. R., Ma, Z. Y., 2008, "Effect of pre-strain and two-step ageing on microstructure and SCC of 7050 alloy.” Mater Sci and Eng A 494, pp.360 - 366.

[38] Feng Wang, Baiqing Xiong, Yongan Zhang, Baohong Zhu, Hongwei, Zixing Wang, Xiaoqing He, 2008, "Microstructure and Mech. Properties of spray-deposited Al 10.8Zn$2.8 \mathrm{Mg}-1.9 \mathrm{Cu}$ alloy after two-step ageing treatment at $110^{\circ} \mathrm{C}$ and $150^{\circ} \mathrm{C}$. Mater Character, 58, pp.82-86.

[39] Daimon K. Heller, William G. Fahrenholtz, Mathew J. O’Keefe, 2010, “The effect of post-treatment time and temperature on cerium-based Conversion coatings on $\mathrm{Al}$ 2024-T3.” Corrosion Science, 52, pp.360-368.

[40] Risanti, D. D., Yin, M., Rivera Diazdel Castillo, P.E.J., Vau der Zwang, S., 2009, "A systematic study of the effect of interrupted ageing conditions on the strength and toughness development of AA6061." Mater Sci and Eng A523, pp.99-111.

[41] Bhatnagar, P. P., Banerjee, T., 1960, "Aluminium-Silicon alloy.” Transactions: India Institute of Metals, T. P. 43, Pp.219-230.

[42] Brooks, C. R., 1982, "Heat treatment, structure and properties of Nonferrous alloys, ASM, Ohio, USA.

[43] Abdulrahman, A. S., Aigbodion, V. S., "The effect of ageing temperature on the corrosion characteristics of Al-Si-Cu alloy in concentrations of $\mathrm{HCl}$ acid.” J. Eng Sci and Techn, Vol. 1, No. 1, pp.82-86.

[44] Khoshnaw, F. M., Gardi, R. H., 2007, "Effect of ageing time and temperature on exfoliation corrosion of aluminium alloys 2024-T3 and 7075-T6." Mater and Corrosion, Vol. 58, No 5, pp.345-347.

[45] Madugu, I. A., Abdulwahab, M., 2006, "The effect of $\mathrm{Cr}$ addition on the mechanical properties of Al-Si-Fe alloy.” J. Res. Eng, Vol 3, No 4, pp. 29-33.

[46] Osorio Wislei, R., Jose E. Spinelli, Celia M.A. Freire, Marganta B. Cardona, Amauri Garcia, 2007, "The role of $\mathrm{Al}_{2} \mathrm{Cu}$ and its dendritic refinement on surface corrosion resistance of hypoeutectic Al-Cu alloys immersed in $\mathrm{H}_{2} \mathrm{SO} 4$." J. Alloys and compds 443, pp.87- 93.

[47] Andreatta, F., Terryn, H., De Wit, J. H. W., 2004, "Corrosion behaviour of different tempers of AA7075 aluminium alloy." Electrochem Acta, 49, pp.2851-2862.

[48] Zaki Ahmed, Abdul Aleem, B. J., 2002, "Degradation of aluminium metal matrix composites in salt water and its control." Mater and Design, 23, pp.173-180.

[49] Burleigh, T. D., Rennick, R. C., Bovard, F. S., 1993, Corrosion, 49, 683.

[50] Wloka Joachim, Theo Hack, Sannakaisa Virtanen, 2007, "Influence of temper and surface condition on the exfoliation behavior of high strength Al-Zn-Mg-Cu alloys." Corrosion science, 49, pp.1437-1449. 
[51] Singh Preet, M., Lewandowski John, J., 1995, "Effects of heat treatment on stress corrosion cracking of a discontinuously reinforced aluminium 7XXX alloy during slow strain testing." Scripta Mater, Vol. 33, No 9, pp.13930-1399.

[52] Ramgopal, T., Gouma, P. I., Franke, G. S., 2002, " Role of grain-boundary precipitates and solute depleted zone on the intergranular corrosion of aluminium alloy 7150.” Corrosion, Vol. 58, No 8, pp.687-697. 